\title{
The Problems of Legal Gaps to the Protection of Women Against Domestic Violence in Ethiopia
}

\author{
Lamessa Gudeta Guder \\ Western Shoa Zone Attorney Office, Ambo, Ethiopia \\ Email address: \\ lamgudee@gmail.com \\ To cite this article: \\ Lamessa Gudeta Guder. The Problems of Legal Gaps to the Protection of Women Against Domestic Violence in Ethiopia. International \\ Journal of Law and Society. Vol. 2, No. 2, 2019, pp. 16-21. doi: 10.11648/j.ijls.20190202.11
}

Received: June 8, 2019; Accepted: July 11, 2019; Published: July 23, 2019

\begin{abstract}
Domestic violence is the most common form of violence experienced by women around the world which is directed by their intimate partner and other family members, and manifested through; physical, sexual, psychological and economic abuse. Domestic violence against women exists in countries with varying social, political, economic, and cultural structures, and its pervasiveness signifies that the problem does not originate with the pathology of an individual person. In Ethiopia, domestic violence is very prevalent throughout the country. However, building strong legal frame work is a cornerstone for the protection of women's rights against any sexual based discrimination and violence. Accordingly, targeting at providing better protection to the rights of women, Ethiopia has attempted to undertaken significant 'gender-sensitive' legislative reforms after the down fall of military junta. Foremost among these laws; the 1995 FDRE constitution, the 2003 Revised Family Law and the 2005 Revised Criminal Code are indicative. However, regarding the scope of coverage of laws dealing with VAW, the Ethiopian legal framework cascades dump of the internationally accepted standards. Different forms of violence against women have not be criminalized in the way of understanding the complexity nature of the violence though international standards require States to ensure that forms of violence against women are included in criminal law as criminal acts.
\end{abstract}

Keywords: Domestic Violence, Legal Framework, Women, Criminalize, Physical, Sexual

\section{Introduction}

Protecting women from any gender based violence are very crucial for the development of certain country. Because, women are half of the society-unless their rights are protected and empowered equally with men their contribution would be decreased. Accordingly Combating domestic violence and any gender based violence against women needs to enacting strong legal framework. To this end, there are different laws in Ethiopia though have certain problems. The principle of equality is enshrined in the FDRE Constitution of the country as well as all relevant subsidiary legislation. Further, the Constitution provides that internationally agreed standards ratified by the country as integral part of the Ethiopian law [1]. Accordingly, the international standards adopted in instruments ratified by Ethiopia like CEDAW [2] constitute part of the law of the land. However, regarding the scope of coverage of laws dealing with VAW, the Ethiopian legal framework cascades dump of the internationally accepted standards. Different forms of violence against women have not be criminalized in the way of understanding the complexity nature of the violence though international standards require States to ensure that forms of violence against women are included in criminal law as criminal acts.

\section{Methodology of the Study}

The qualitative methodology was primarily used and applied to examining legal gap and socio structural risk markers for domestic violence in this study. As such, in terms of source of data, both primary and secondary resources were employed in the study. The existing legal documents of the country such as domestic policy, legislation, directives and guidelines has been used to identify and evaluate the existing policy and legal frame work against domestic violence in the country. The research mainly depends on semi-structured interviews with a list of identified topics to cover and focused 
group discussions. FGD and interview has been conducted with selected professional in courts, justice office, police investigation departments, women's and child affairs office.

\subsection{The Legal Responses to Physical Violence Against Women}

Physical abuses are high prevalence in Ethiopia and most of the women are battered by their husband in each single day. Many participant of FGD conducted reveal that, the abuse extends from slap to the use of weapons resulting in death. Most of them bore visible scare, bruise and cuts on their bodies. Despite the gravity of the problems, our criminal code doesn't give much attention as such. The code has not put comprehensive definition and scope of the term violence against women as was done under the CEDAW and/or African Protocol [3].

Domestic violence is dealt under the provision on violence against a marriage partner or a person cohabiting in an irregular union. The law treats this kind of violence in the same manner as any form of assault committed on any person irrespective of the nature of the crime. However, cases of DVAW have special characteristic features. For example they are committed repeatedly, occur in situations where the woman is under the influence of the man; mainly where she is economically dependent, it is a manifestation of power of men over women. Also the crime of DVAW is committed at behind the closed door in hidden place and complex phenomena, committed in the situation even evidence cannot be obtained to press the criminal charges against the perpetrator. As such, it is sexual oriented violence which occurs up on the relationship between the perpetrator and the victim- in the situation where a victim owes believes to the perpetrator up on their special relationship. Physical VAW is an act of violence that results in physical harm and/or suffering to women and is perpetrated against women because of their gender. This aspect of the definition is missing from the law as the law deals with cases of DVAW by making cross-reference to cases of assault and willful injury. Article 564 is the single provision with explicit reference to the term domestic violence in the code. The excerpt of this article read as,

Violence against a Marriage Partner or a Person cohabiting in an Irregular Union.

The relevant provision of this Code (Arts. 555 - 560) shall apply to a person who, by doing violence to a marriage partner or a person.

Co-habiting in an irregular union, causes grave or common injury to his/her physical or mental health [4].

The problem is that, this article is not only narrowed the type of domestic relationships to marriage partner and person co-habiting in an irregular union but also refers back to the provisions dealing with crimes against person and health (Articles 555-560) for determination of its criminality and punishments. It seems like simple incidental statement; the code has not as such created an offence of domestic violence in its own right in separate and clear provisions. Rather humbly it assimilates to ordinary assault and battery; grave or willful physical injuries.

As such it fails to recognize a crucial element of DVAW that, it is violence perpetrated against women because they are women. It doesn't consider the special nature of domestic violence, where the victim is usually in a relationship of dependence with the perpetrators. Rather, merely equating cases of DVAW to assault and treating them as such, the law fails to take into account these gendered features. At this juncture, it is worthy to raise the issue that, does article 564 of FDRE criminal code adds something to protection of women against DV? As mentioned above, it simply refers to Arts. (555-560) [5]. We can understand from this provision that, even when article 564 were not included in FDRE criminal code, the enforceability of Article (555 - 560) is inevitable. This indicates that inclusion and, or exclusion of article 564 has no effects on the enforceability of Article (555 - 560) for all physically abused persons including intimate partner abuse. Hence article 564 has added nothing special to the protection of women against domestic violence. This in turn shows that, physical abuse against women in domestic sphere does not properly addressed as much as needed in FDRE criminal code. Such legal lacuna has been manifested in practice in most parts of the country as challenges to protection women against domestic violence.

\subsection{The Legal Response to Sexual Violence Against Women}

Women's experiences with sexual violence varied along a ranging from battering rape and bullying to threats, verbal humiliation and non-physical forms of pressure that compelled them to engage in sex against their will [6]. In an abusive relationship, sex is just another form of male control in an effort to gain the woman's complete acquiescence. These strategies of control often focused directly on the female victim's body and sexuality. As data obtained from participants, the forced sexual act becomes one; in which the woman is silenced, controlled and subordinated.

Sexual violence in marriage is clearly an issue of gender inequality, in which a woman is forced to give in to her husband's demands [7] Women experienced rape or physically forced sex in the context of a battering relationship. The data gathered from FGD show that, Women are not willing to call their experiences as rape, which could be a sign that the concept of marital rape is rather absent in the Ethiopian culture.

Sexual assault including rape and sexual harassment by outsider are addressed with in the criminal law. However, the provision on rape clearly excludes instances of marital rape. The data congregated from participants of FGD in justice office indicate that, the exclusion of marital rape from rape punishable by law under the Ethiopian Criminal Code contributes to the prevalence of marital rape in Ethiopia. Since there are no legal consequences for rape committed within wedlock, men continue to rape their wives, and this has severe physical and psychological repercussions for such victims. The right to refuse sex in marriage is not accepted and still remains 'unthinkable' for all women and men in different districts. This clearly excludes the majority of cases 
where by hostile working, living and learning environments are created due to the threat caused by demands of sexual favors. In 100 countries across the world, marital rape is a criminal offence and is punishable by law [8]. For instance; in South Korea, Japan, Philippines and Taiwan, marital rape has been criminalized.

In Ethiopia, however, marital rape is not considered to be a crime under the Ethiopian criminal law system. When we see article 620 of FDRE Criminal code, it apparently legalized the wedlock rape. It excerpt read as,

(1) Whoever compels a woman to submit to sexual intercourse outside wedlock, whether by the use of violence or grave intimidation, or after having rendered her unconscious or incapable of resistance, is punishable with rigorous imprisonment from five years to fifteen years.

On this juncture, the phrase 'outside wedlock' clearly indicates, the legality of wedlock rape which has consequences of great healthy and psychological problems on the victim. Although the CEDAW Committee urged Ethiopia to amend its criminal law in order to criminalise marital rape, in its concluding observations on the country in 2011, the legislature still failed to comply with the request of the Committee [9]. It exempts rape committed within wedlock from punishment. As raised by participants of interviews, due to the exemption of marital rape from punishment under the Criminal Code, men have been using their marital status as a license to rape their wives. And law enforcement authorities by themselves have been abstained from interfering into sexual abuse between intimate partners.

For instance, one prosecutor quotes that,

"most of the time, sexually abused women has been coming to investigation office, however, we could not conduct investigation on this issue since we have no legal support. we simply send back them to home, or order to go to court to seek divorce and hospital to treatment" [10].

The fact that the Criminal Code does not recognised marital rape as a crime discourages the police from conducting investigations and taking action. Many data assembled from participants in interview conducted with judges, prosecutors and police reveal that, decriminalization of marital rape is preventing them even from investigation and prosecuting the alleged offender. Other participants pinpoint that, due to the lack of relief after reporting incidents of marital rape, women are discouraged from making further reports when the incident is repeated.

\subsection{The Legal Response to Psychological Violence Against Women}

As the results of the literature and the participants of focused group discussion shown; insults, belittling, verbal aggression and constant humiliation are the common forms of psychological violence directed against women in Ethiopia. The participants of interview conducted with professionals of court and Justice office often say that the psychological abuses and degradation are even more difficult to bear than physical abuse. Verbal humiliation, such as being called names, sworn at or put down were seen and reported in most parts of the zonal districts. It has been manifested and reported through seeking divorce in civil cases rather than through criminal proceedings. For instance, one Judge quotes that,

"Psychological abuse is one of the causes of divorce in addition to other abuses.

Most of the time, when women faced DV, they do not want to criminal remedies to their abuse rather they seek divorce in the court of law.

And DV is the very causes for the increments of divorce." [11]. From this we can understand that, the problem of legal gap in criminalization of domestic violence abuses leads to the increments of divorces. And the anger of violence are manifested through divorce. Violence described in terms of emotional or psychological abuse, referring to situations in which a man might constantly insult or undermine a woman. And Women disproportionately suffer from these types of violence because they are women. As data gathered from participants of FGD held with prosecutor shows, it has very adverse effects on women inter alia, demoralized women and trapped in abusive relationships, make them perceived as inferior to men cognitively, and make them to be submissive, obedient and respectful of their husband. It hart women's self-confidence and makes them to be emotionally dependent.

However, the Ethiopian law doesn't give attention to such humiliating nature of psychological violence against women and treat similar to other ordinary insult, or threat. The law treating these forms of violence irrespective of the sex/gender of the perpetrator and victim as well as the prevailing gender relations fails to capture and address the gendered nature of the violence.

When we see the FDRE criminal code thoroughly, there are different ordinary provisions applicable to any person irrespective of sexual relationships, or social status and, or other parameter which aimed to criminalize some psychological harms. For instance article (607-619) of FDRE criminal code talks about Crimes against honours or reputation, defamation and calumny, insults or outrage [12]. On other hand Article (580-585) criminalizes the offence of intimidation, threat to accusation or disgrace, coercion, deprivation of power of decision and illegal restraints [13]. These wordings of provision don't consider any special nature of psychological violence directed against women. It simply stipulates the provision applicable to any person and it did not benefit women because of special nature of domestic violence against women which needs to give more attention in all circumstances of investigation and prosecution.

Accordingly, although the law recognizes psychological harm, the coverage is not adequate for protection of women against domestic violence since it does not take into account the complexity nature and hidden commission of DVAW which in turn needs to promulgate special and separate laws to guide all the process of obtaining evidences and the prosecutions of DV cases. For instance many countries including Latin American countries have enacted specific 
domestic violence laws that combine criminal offences and civil protections. Most of these laws include psychological violence in the definition of domestic violence [14].

\subsection{The Legal Response to Economic Violence Against Women}

Economic abuse is another form of abuse in which women are the primary victims. Men have traditionally controlled and dominated the financial assets of the family, and have retained the power to make financial decisions within the family. As data gathered from participants of FGD conducted with professionals of women's and child affairs office shows, there are different reports; economic or financial abuse involves the control of the use and availability of money, preventing her participation in money-spending decisions and refusing to give her money for basic household necessities. It involves an act that aimed at disempowering women by denying them access to and control over basic resources. When women fail to comply with their demand, they can punish and threatening them by refusing to give them money and physically assaulting them. Financial domination; like psychological, physical and sexual abuse, has the great negative effects on women's emotional, social and physical well-beings.

However, the issue is that, our laws seem to ignore such old-scourge economic abuses directed against women. The absence of appropriate legal frame work to punish such perpetrator of economic violence leads to validation of such abuse against women. For instance, if a husband refuses to his wife to access health care by denying her resources/money, control of the use and availability of money, preventing her participation in money-spending decisions and refusing to give her money for basic household necessities what is the available legal recourse?

The participants of interview explain their concern regarding the absence of specific legal framework against the economic abuse directed against women. They added that, there are no ways to distinguish the acts that constitutes a domestic violence even to those persons. For instance it has not taken into consideration the different aspects of domestic violence such as the economic abuse. All these clearly show that, the Ethiopian laws don't recognize in preventive manner the forms of domestic violence against women. This in turn makes DVAW as lawful act which has great challenges to the protection of women.

\subsection{Absence of Protection Order for Victims or Survivors (Civil Remedy)}

In proceeding topics, we have discussed the inefficiency of our laws to criminalizing patters of domestic abuses. But under this topic we try to look whether civil remediesprotection order were not available for victims in our laws. The data gathered from the participants of interviews divulge that, Ethiopian law is deprived of specific civil remedies against domestic violence. There has been no separate domestic violence act or law which provides specific civil remedies for victims/survivors which includes; the right to obtain protection order, actions for damages against the perpetrator, the police or third parties who fail to prevent the violence, governmental victim compensation funds, monetary/compensation relief, custody order, residence order, shelter or medical benefits or more than one such order.

As such protection orders are essential criminal or civil justice measures aimed at preventing further violence from happening and protecting victims. The participants of FGD conducted with judges explain that, such remedy has of paramount importance for victims. It provides victims with time to reflect on what their options are in terms of safety, and to decide about their future.

The protection orders serves as a deterrent measure. Because, it send messages to the perpetrators that, their behavior is not acceptable and that there will be consequences for their actions. Such measures also prevent the perpetrator from approaching or contacting the victim or allow the removal of the perpetrator from the joint dwelling or that of the victim for a specific period of time. The purpose of restraining or protection orders is to offer a fast legal remedy to protect people at risk. Many participants of interviewed support the necessity of protection order. If there are protection orders, it is better for the victim, even it prevent the double victimization, shorten the process of remedy to victim, give high protection in simple procedure. One informant from professionals of women and child affairs office told me that,

"Abused women (physical, sexual and psychologically injured) reported to us. We cannot give any protection order to victims, nor court order protection directly rather than stringent procedure through police which is very difficult for abused women. We simply call the abuser and warned. Then we send back both the victim and abuser. But after that, abuser abused victim again. We remembered the circumstance, when abuser chopped the victim in to pieces and kill her after went to home" [15].

It is encouraged that both criminal and civil remedies should be made available for the effective prevention and redress in cases of violence against women. In Ethiopia, there is tort law provided in civil code under article 2035 [16] regarding for the compensation to the arisen damage. However, it is not adequate and out dated in terms of amount of compensation and coverage. It does not consider the unique nature of domestic violence against women. It has no protection order in case of domestic violence. On the other hand, the system of a tort action provided in civil code will not address immediate needs of women's reality. Therefore, such problem prays the enactment of complied DV law which may include all possible civil remedy and different protection orders along with criminalization. Many countries include civil remedies in their domestic violence law [17]. For instance, in the United States, victims of violence can seek civil damages from the perpetrator for infliction of violence, and in some circumstances, from the police or other actors who should have prevented the violence but failed to do so. 


\section{Data Analyzing Methods}

The researcher used interpretational analysis approach and descriptive for this study. Each session was followed by preliminary analysis that included verbatim transcription of Oromic translation into English, and continuing the data collection until a point of saturation. Accordingly, the data generated from focus group discussion and in depth interview were divided in to different categories/themes. Categories were formed keeping the objective of the study in mind as much as possible and similar categories were brought together. Accordingly, the major concepts were interpreted by repeated reading through the categories, notes and memos, summarizing, and then verified.

\section{Result and Discussion}

Criminalizing offences of gender based violence is considered as major step in the protection of women's rights against any abusive acts of perpetrators. Because- legal framework is the first measures that needs to have been taken to illegalize or legalize certain acts. Accordingly, Ethiopia has enacted FDRE criminal code. The Revised Criminal Code of the Federal Democratic Republic of Ethiopia (The Criminal Code, 2004) is the major areas of Ethiopian law that has been revised in conformity with the FDRE constitution and includes different new and revised provisions that are of pertinent to the protection of women from violence by criminalizing different offences. The Code addresses violence against women in different forms. Accordingly, the code criminalizes most forms of violence against women and girls including rape outside wedlock, trafficking of women, prostitution of another for gain, and physical violence within marriage or in an irregular union- to some extent, abduction, Female genital mutilation, and early marriage [18].

As discussed above, Physical VAW is an act of violence that results in physical harm and/or suffering to women and is perpetrated against women because of their gender. This aspect of the definition is missing from the law as the law deals with cases of DVAW by making cross-reference to cases of assault and willful injury. Article 564 is the single provision with explicit reference to the term domestic violence in the code. The problem is that, this article is not only narrowed the type of domestic relationships to marriage partner and person co-habiting in an irregular union but also refers back to the provisions dealing with crimes against person and health (Articles 555-560) for determination of its criminality and punishments. It seems like simple incidental statement; the code has not as such created an offence of domestic violence in its own right in separate and clear provisions. Rather humbly it assimilates to ordinary assault and battery; grave or willful physical injuries.

This in turn shows that, physical abuse against women in domestic sphere does not properly addressed as much as needed in FDRE criminal code. Such legal lacuna has been manifested in practice in most parts of the country as challenges to protection women against domestic violence.
In Ethiopia, however, marital rape is not considered to be a crime under the Ethiopian criminal law system. When we see article 620 of FDRE Criminal code, it apparently legalized the wedlock rape. Sexual assault including rape and sexual harassment by outsider are addressed with in the criminal law. However, the provision on rape clearly excludes instances of marital rape. Since there are no legal consequences for rape committed within wedlock, men continue to rape their wives, and this has severe physical and psychological repercussions for such victims.

The FDRE criminal code thoroughly, there are different ordinary provisions applicable to any person irrespective of sexual relationships, or social status and, or other parameter which aimed to criminalize some psychological harms. It doesn't consider any special nature of psychological violence directed against women. It simply stipulates the provision applicable to any person and it did not benefit women because of special nature of domestic violence against women which needs to give more attention in all circumstances of investigation and prosecution. Hence although the law recognizes psychological harm, the coverage is not adequate for protection of women against domestic violence since it does not take into account the complexity nature and hidden commission of DVAW which in turn needs to promulgate special and separate laws to guide all the process of obtaining evidences and the prosecutions of DV cases.

As we understand from the provision of FDRE Criminal code, though, the criminal code criminalizes different forms of violence against women; it doesn't give much attention to the domestic violence against women. However, domestic violence is not simple and forgettable violence since it has consequences of serious healthy, economic and social problems as discussed earlier. The majority of participant in FGD raised that, the FDRE criminal code doesn't criminalize many forms of domestic violence against women and DVAW did not have much attention in this criminal code. Undeniably, such kind of assertion is valid as everyone can understand from criminal code. Therefore, such legal lacuna may be great challenges for our justice system in protection of WADV in general.

\section{Conclusion}

Protecting women from any gender based violence are very crucial for the development of certain country. Because, women are half of the society-unless their rights are protected and empowered equally with men their contribution would be decreased. Accordingly Combating domestic violence and any gender based violence against women needs to enacting strong legal framework. To this end, there are different laws in Ethiopia though have certain problems. The principle of equality is enshrined in the FDRE Constitution of the country as well as all relevant subsidiary legislation. Further, the Constitution provides that internationally agreed standards ratified by the country as integral part of the Ethiopian law. Accordingly, the 
international standards adopted in instruments ratified by Ethiopia like CEDAW constitute part of the law of the land. However, there are the problems of the scope of coverage of laws dealing with DVAW and extent of punishment. The Ethiopian legal framework falls short of the internationally accepted standards concerning DVAW. Different violence against women does not be criminalized in the way of understanding the complexity nature of the violence, though International standards require States to ensure that forms of violence against women are included in criminal law as criminal acts.

The findings show that, FDRE criminal code doesn't criminalize many forms of domestic violence against women which may include; the sexual, psychological and economic abuse. And DVAW did not have much attention in this criminal code. It criminalized physical violence only in some extent. But this by itself did not add something to protection of WADV since it simply refers to the provision of ordinary physical injury. Undeniably such legal lacuna may possibly raise as challenges for our justice system in protection of WADV in general.

\section{References}

[1] The Constitution of the Federal Democratic Republic of Ethiopia, Proclamation No. 1/1995 Article 9 (4).

[2] Convention on the Elimination of All Forms of Discrimination Against Women (adopted 18 December 1979, entered into force on 3 September 1981) United Nations, Treaty Series, vol. 1249 , article 1 ,

$<$ http://www.unhcr.org/refworld/docid/3ae6b3970.html> accessed 18 April 2019.

[3] African Union, Protocol to the African Charter on Human and Peoples' Rights on the Rights of Women in Africa, 11 July 2003, UN, Commission on the Elimination of Discrimination Against Women, General Recommendation No. 19: Violence Against Women, 11th Sess., 4, U. N. Doc. A/47/38 (1993).

[4] FDRE Criminal Code (n 2) Article 564.

[5] FDRE Criminal Code (n 2) Article 555-560.
[6] Myhill A, et al, Rape and Sexual Assault of Women: The Extent and Nature of the Problem: Findings from the British Crime Survey (Home Office Research, Development and Statistics Directorate 2002) 42.

[7] Pracher M, 'The Marital Rape Exemption: A Violation of a Woman's Right of Privacy' (1981) 11 Golden Gate University L Rev. 3.

[8] Sharma K, Behind the Locked Doors: The Evil of Marital Rape, <http:/www.mightylaws.in/1246/locked-doors-evilmarital-rape $>$ accessed 4 April 2019.

[9] Committee on the Elimination of Discrimination against Women, Concluding observations of the Committee on the Elimination of Discrimination against Women-Ethiopia Fortyninth Session, 11-29 July, 2011, para 21.

[10] An interview conducted with prosecutor by researcher on 22 April 2018.

[11] An interview conducted with the court by researcher on 21 April 2018.

[12] FDRE Criminal code (n 2) article (607-619).

[13] FDRE Criminal code (n 2) Article (580-585).

[14] UNDAW, Good practices in combating and eliminating violence against women, United nations division for the advancement of women (17- 20 May 2005 Vienna, Austria) 12.

[15] Interviews conducted with professional of women and child affairs by the researcher at Jimma town on 12 April 2018.

[16] Civil Code of the Empire of Ethiopia, Proclamation No. 165 / 1960 Article 2035.

[17] UNDAW, Good practices in combating and eliminating violence against women, United nations division for the advancement of women (17- 20 May 2005 Vienna, Austria) 23.

[18] FDRE Criminal code (n 2) -see provision; trafficking women (article 597), prostitution of another for gain (article 634), and physical violence within marriage or in an irregular union (article 564), abduction, (articles 587, 590), Female Genital Mutilation (articles 565-6), and early marriage (article 649). 